\title{
Prevalence of Metabolic Syndrome Components in an Urban Mexican Sample: Comparison between Two Classifications
}

\author{
Irma Isordia-Salas, ${ }^{1}$ David Santiago-Germán, ${ }^{1,2}$ Helem Rodrìguez-Navarro, ${ }^{1}$ \\ Martín Almaráz-Delgado, ${ }^{3}$ Alfredo Leaños-Miranda, ${ }^{4}$ Francisco Anaya-Gómez, ${ }^{5}$ \\ Gabriela Borrayo-Sánchez, ${ }^{6}$ and Abraham Majluf-Cruz ${ }^{1}$ \\ ${ }^{1}$ Unidad de Investigación Médica en Trombosis, Hemostasia y Aterogénesis, HGR No. 1 "Dr. Carlos Mac Gregor Sánchez Navarro" \\ Instituto Mexicano del Seguro Social, CP 06720, México, DF, Mexico \\ ${ }^{2}$ Escuela Nacional de Ciencias Biológicas, Instituto Politécnico Nacional, CP 07738, México, DF, Mexico \\ ${ }^{3}$ Jefe del Laboratorio Clínico del, HGR No. 1 “Dr. Carlos Mac Gregor Sánchez Navarro” Instituto Mexicano del Seguro Social, CP 06720, \\ México, DF, Mexico \\ ${ }^{4}$ Unidad de Investigación Médica en Medicina Reproductiva, UMAE HGO 4, Instituto Mexicano del Seguro Social, México, DF, Mexico \\ ${ }^{5}$ Servicio de Medicina Interna, HGR No. 1 “Dr. Carlos Mac Gregor Sánchez Navarro” Instituto Mexicano del Seguro Social, CP 06720, \\ México, DF, Mexico \\ ${ }^{6}$ Hospital de Cardiología, Centro Médico Nacional Siglo XXI, Instituto Mexicano del Seguro Social, CP 06720, México, DF, Mexico
}

Correspondence should be addressed to Irma Isordia-Salas, irmaisordia@yahoo.com.mx

Received 2 July 2011; Revised 11 August 2011; Accepted 25 August 2011

Academic Editor: Jun Ren

Copyright ( $) 2012$ Irma Isordia-Salas et al. This is an open access article distributed under the Creative Commons Attribution License, which permits unrestricted use, distribution, and reproduction in any medium, provided the original work is properly cited.

\begin{abstract}
Background. The aim of this study was to examine the prevalence of metabolic syndrome (MS) components in an urban Mexican sample. Methods. A total of 854 subjects were included. Anthropometric, blood pressure measurements, clinical data, and overnight fasting blood samples were obtained from all subjects. Results. In accordance with definitions by the American Heart Association/ National Heart, Lung, and Blood Institute (AHA/NHLBI) and the International Diabetes Federation (IDF), the prevalence of MS among participants was 59.7 and 68.7\%, respectively. The prevalence of MS was higher in women and in individuals older than 45 years of age. More than $40 \%$ of the subjects fulfilled four criterions of MS according to both definitions. Conclusions. There was a high prevalence of MS components in an urban Mexican sample. Therefore, strong strategies had to be developed for early detection of MS and its components to prevent DMT2 and atherothrombotic complications in these patients.
\end{abstract}

\section{Introduction}

he original description of the metabolic syndrome (MS) by Reaven [1] consisted of abdominal obesity, insulin resistance, high blood pressure, impaired glucose tolerance or diabetes, hyperinsulinemia and dyslipidemia characterized by elevated triglyceride, and low HDL concentration. All of the features described above are risk factors for atherosclerosis, and thus MS constituted a significant risk for atherothrombosis disease. The World Health Organization in 1998 [2] and the Adult Treatment Panel III (ATP III) in 2001 standardized the definitions of MS [3]. In 2005, The International Diabetes Federation (IDF) formulated a new definition of the MS in a global consensus statement [4]. The prevalence of MS in adults varies from one population to another worldwide. Several studies indicate that, in USA, one-third of adults [5] with an alarming proportion of adolescents and children $[6,7]$ have the MS. Also a high prevalence of MS in Europe has been demonstrated [8]. It was reported that nondiabetic subjects under 40 years of age had an MS prevalence of $14-41 \%$, depending on the age range [8]. In Mexico, several studies had documented a high prevalence of MS [9, 10], with an increased tendency due to changes in lifestyle behavior (overweight and obesity, physical inactivity, high carbohydrate diets, alcohol, and tobacco consumption) and genetic predisposition. The prevalence of the components 
of MS is increased in obesity [11] and is associated with atherothrombotic complications in micro- and macrovascular territories $[12,13]$. The syndrome is also strongly associated with the increased risk of coronary heart disease and type 2 diabetes mellitus (T2DM) [14-17]. The abnormal metabolic state that accompanies diabetes causes arterial dysfunction. Relevant abnormalities include chronic hyperglycemia, dyslipidemia, and insulin resistance $[18,19]$. Atherothrombotic disease is the leading cause of dead worldwide and is the result of genetic and environmental factors $[20,21]$.

We have previously identified genetic variants associated with myocardial infarction and stroke in Mexican young population, in whom components of MS are present [22, 23]. Therefore, the aim of this study was to examine the prevalence of components of syndrome (MS), among Mexican adult population, and to evaluate the genetic participation in this group of patients with high vulnerability to T2DM and atherothrombotic disease.

\section{Materials and Methods}

We conducted a study to identify the prevalence of MS components using two definitions: the IDF and AHA/NHLBI in an urban Mexican sample from Mexico City. Individuals $>20$ years of age were invited to participate in the study if they were interested to know the risk to develop cardiovascular disease or T2DM. The recruitment period lasted for 1 year (1 May-30 May 2011). All included subjects provided the informed written consent to participate in the study.

2.1. Methods. Subjects were interviewed privately by a physician using pretest questionnaires. The following, demographic and clinical data were collected at the time of the interview: sex, age, cigarette smoking previous diseases, familial history of diabetes, and atherothrombotic disease.

Waist circumference (WC) was measured at the midpoint between the last rib and the iliac crest with participants standing and wearing only undergarments. Body weight was measured by precision scale while subjects were minimally clothed without shoes. Height was measured in a standing position without shoes using tape meter while the shoulders were in a normal state. Body mass index (BMI) was calculated as weight in kilograms divided by height in meters squared. Patients were defined as overweight with BMI of $25.0-29.9 \mathrm{~kg} / \mathrm{m}^{2}$, and obese with a BMI $\geq 30 \mathrm{~kg} / \mathrm{m}^{2}$. All measurements were taken by the same person. Blood pressure (at rest) was measured with the participant seated. Two readings were taken in 5-minute interval between these two separated measurements, and thereafter the mean of the two measurements was considered to be the participant's blood pressure. The subjects were considered smokers if they were currently smoking (regularly or occasionally, including also former smokers defined as people who stopped smoking at least one year before the examination). A familial history of atherothrombotic disease was defined as acute myocardial infarction (AMI), stroke, or sudden death in a first-degree male relative younger than 55 years of age or a female relative younger than 65 years of age.
2.2. Laboratory Methods. In the morning, after an overnight fast, venous blood was sampled for the measurements of the serum glucose, total and HDL cholesterol, triglycerides, hs-CRP, uric acid, and plasma concentration of fibrinogen. Plasma low-density lipoprotein (LDL) cholesterol was calculated with the equation of Friedewald et al. [24], except when triglycerides exceeded $400 \mathrm{mg} / \mathrm{dL}$. Buffy coat was collected and frozen for genetic studies.

Plasma levels of LDL, fibrinogen, uric acid, hs-CRP, and $\mathrm{HbAlc}$ were considered high if they were above $160 \mathrm{mg} / \mathrm{dL}$, $400 \mathrm{mg} / \mathrm{dL}, 6 \mathrm{mg} / \mathrm{dL}$ in women and $7 \mathrm{mg} / \mathrm{dL}$ in men, $3.0 \mathrm{mg} /$ $\mathrm{L}$, and $6.5 \%$, respectively.

The study protocol was reviewed and approved by the Human Ethical Committee and Medical Research Council of Instituto Mexicano del Seguro Social and conforms to the ethical guidelines of the 1975 Declaration of Helsinki. Informed written consent was obtained from all subjects before enrollment.

2.3. Diagnostic Criteria of the Metabolic Syndrome. The MS was defined according to each of the IDF and AHA/NHLBI definitions as described in Table $1[4,25]$.

2.4. Statistical Analysis. Continuous data are expressed as the mean \pm standard deviation $(\mathrm{SD})$; categorical data are expressed with percentages. The significance of differences between continuous variables was determined by Student's $t$-test. Differences between categorical variables were determined with the chi-square test. A $P$ value $<0.05$ was considered as statistically significant. All statistical analyses were performed using SPSS (statistical package for the social sciences) statistical software package (version 16: SPSS Inc, Chicago, Il, USA).

\section{Results}

A total of 854 subjects were included in this study (see Figure 1). To ascertain whether different definitions may yield different prevalence, MS was diagnosed on the bases of American Heart Association/National Heart, Lung, and Blood Institute (AHA/NHLBI) and International Diabetes Federation (IDF) criterions (Table 1).

Table 2 shows demographic, clinical, and biochemical features of subjects with MS (MS+), and without MS (MS-). The metabolic syndrome was identified in 607 individuals (407/woman versus $200 /$ men). The mean of age of the subjects MS+ and MS - was similar $(53.4 \pm 11.0$ versus $49.3 \pm$ 13.4, $P=0.43$ ), respectively. The body mass index (BMI) was MS+ $29.9 \pm 4.8$ versus MS $-26.7 \pm 4.2, P<0.001$. There was a statistical significance in terms of waist circumference $(\mathrm{MS}+97.3 \pm 10.8 \mathrm{~cm}$ versus MS $-88.5 \pm 11.5 \mathrm{~cm})(P=$ $0.001)$. There was a higher triglycerides levels in the group of MS+ compared with MS $-(233.8 \pm 220.7$ versus $129.0 \pm 7.3)$ $(P<0.001)$. The high-density lipoprotein cholesterol (HDLC) was lower in the group of patients with MS $(P<0.001)$. There was no differences in total cholesterol between both groups $(P=0.58)$. The concentration of fibrinogen, uric acid, and HbAlc was higher in the group of MS+, compared with MS-. 


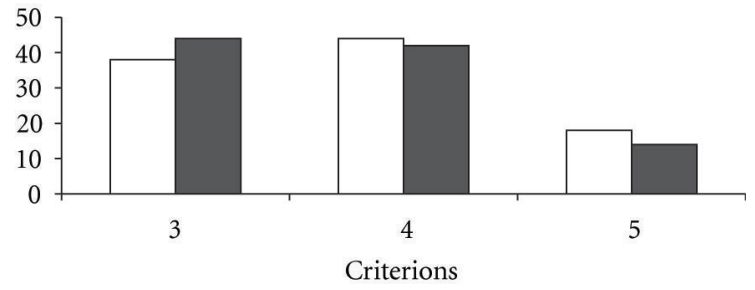

$\square$ IDF
$\square$ AHA/NHLBI

(a)

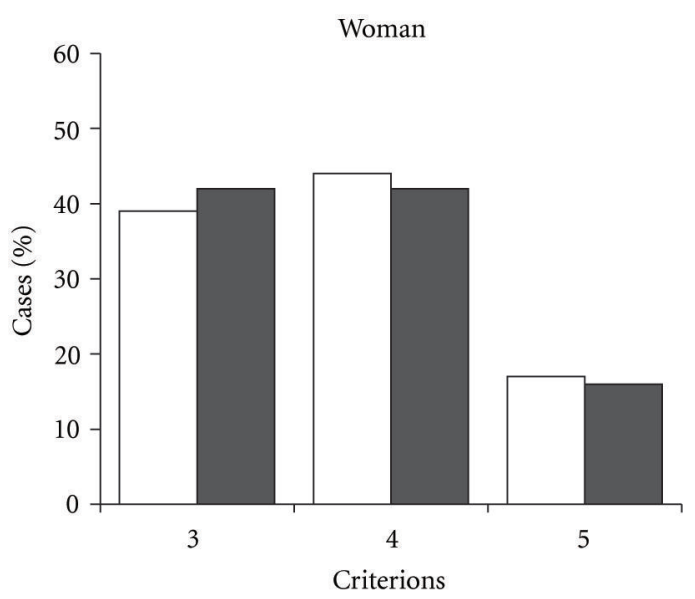

(b)

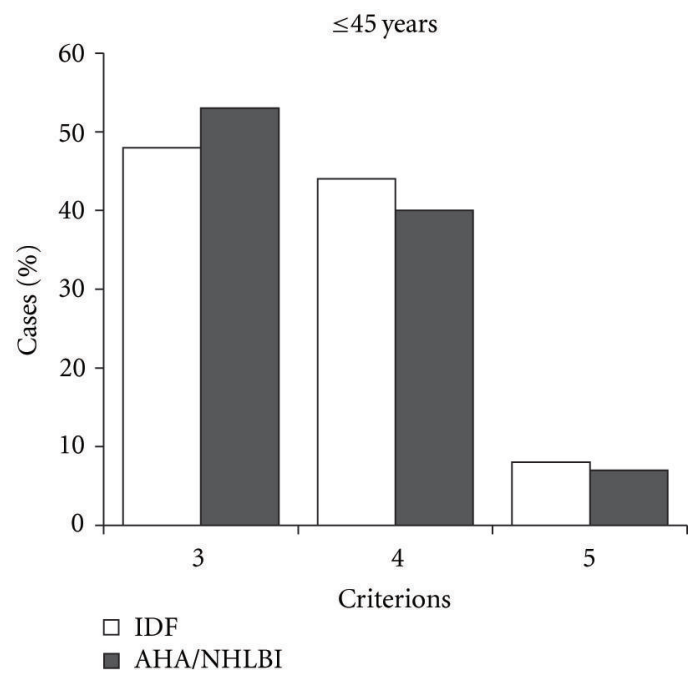

(d)

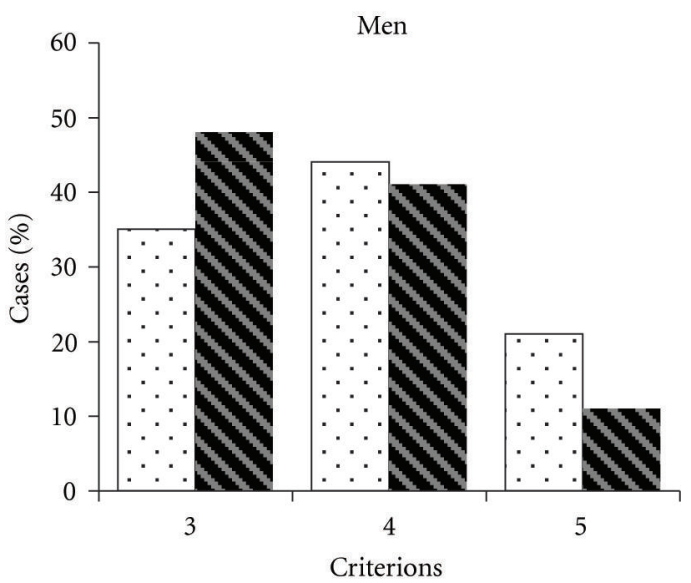

(c)

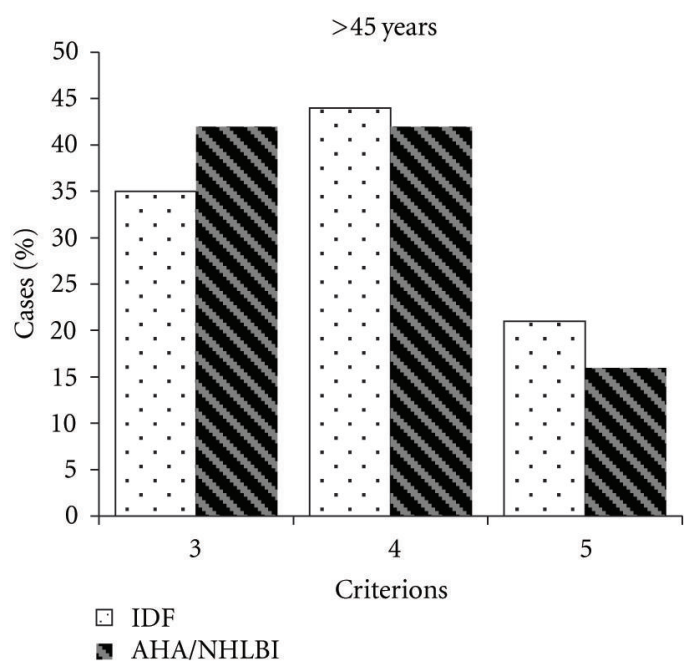

(e)

Figure 1: Percent of patients with number of criterions based on IDF y AHA/NHBLI definitions stratified by sex and age. Regardless of the severity of the metabolic syndrome, we found that $43.7 \%$ of the individuals fulfilled four criterions when MS was diagnosed by IDF, and $45.3 \%$ of the subjects had three components when was used the AHA/NHLBI definition. Similar results were found when we did the analysis stratified by gender. As we expect, in the analysis stratified by age-based MS by IDF and AHA/NHLBI definitions, we found that individuals $\leq 45$ years old fulfilled 3 criterions, whereas four components were present in the older group (43.8\%).

As it was expected there was a higher frequency of cardiovascular risk factors such as smoking, hypertension, and familial history of atherothrombotic disease in the group of individuals with MS. The prevalence of MS diagnosed based on IDF, AHA/NHLBI, or combination of both definitions was $(68.7 \%, 59.7 \%$, and $57.2 \%)$, respectively.
Table 3 shows the analysis of metabolic syndrome according to the IDF definitions. There was no difference in mean of age between men $(53.1 \pm 9.5$ years $)$ and women $(53.7 \pm 11.3$ years). It was more frequent in women $(67.7 \%)$ than in men $(32.3 \%)$. Reduced HDL cholesterol was more frequent in woman $(93.2 \%)$ compared with the group of 
TABLE 1: Criteria for Clinical diagnosis of the metabolic syndrome by the IDF and AHA/NHLBI definitions.

\begin{tabular}{ll}
\hline The IDF definition & The AHA/NHLBI definition \\
\hline $\begin{array}{l}\text { Central obesity: defined as waist circumference } \\
\geq 90 \mathrm{~cm} \text { for Asian men and } \geq 80 \mathrm{~cm} \text { for Asian woman } \\
\text { plus any two of the following four criteria }\end{array}$ & Three or more of the following \\
\hline & $\begin{array}{l}\text { Central obesity: defined as waist circumference } \\
\geq 102 \mathrm{~cm} \text { for men and } \geq 88 \text { for woman }\end{array}$ \\
\hline $\begin{array}{l}\text { Raised fasting plasma glucose }(\mathrm{FPG}): \geq 100 \mathrm{mg} / \mathrm{dL}, \\
\text { or previously diagnosed type } 2 \text { diabetes }\end{array}$ & $\begin{array}{l}\text { Raised fasting plasma glucose }(\mathrm{FPG}): \geq 100 \mathrm{mg} / \mathrm{dL} \\
\text { or previously diagnosed type } 2 \text { diabetes }\end{array}$ \\
$\begin{array}{l}\text { Raised triglycerides } \geq 150 \mathrm{mg} / \mathrm{dL}, \\
\text { or specific treatment for this lipid abnormality }\end{array}$ & $\begin{array}{l}\text { Raised triglycerides } \geq 150 \mathrm{mg} / \mathrm{dL} \\
\text { or specific treatment for this lipid abnormality }\end{array}$ \\
\hline $\begin{array}{l}\text { Reduced HDL cholesterol: } \\
<40 \mathrm{mg} / \mathrm{dL} \text { in males and }<50 \mathrm{mg} / \mathrm{dL} \text { in females }\end{array}$ & $\begin{array}{l}\text { Reduced HDL cholesterol: } \\
<40 \mathrm{mg} / \mathrm{dL} \text { in males and }<50 \mathrm{mg} / \mathrm{dL} \text { in females }\end{array}$ \\
\hline $\begin{array}{l}\text { Elevated blood pressure } \geq 130 / \geq 85 \mathrm{~mm} \mathrm{Hg} \text {, or } \\
\text { previous medical diagnosis of hypertension }\end{array}$ & $\begin{array}{l}\text { Elevated blood pressure } \geq 130 / \geq 85 \mathrm{~mm} \mathrm{Hg}, \text { or } \\
\text { previous medical diagnosis of hypertension }\end{array}$ \\
\hline
\end{tabular}

TABle 2: Demographic, clinical, and biochemical features of subjects with and without metabolic syndrome included in the study.

\begin{tabular}{|c|c|c|}
\hline & MS+ & MS- \\
\hline Subjects $n(\%)$ & $607(70 \%)$ & $247(30 \%)$ \\
\hline \multicolumn{3}{|l|}{ Gender $n(\%)$} \\
\hline Man & $200(33.0 \%)$ & $74(30.0 \%)$ \\
\hline Women & $407(67.0 \%)$ & $173(70.0 \%)$ \\
\hline Age (years) & $53.4 \pm 11.0$ & $49.3 \pm 13.4$ \\
\hline Body mass index $\left(\mathrm{kg} / \mathrm{m}^{2}\right)$ & $29.9 \pm 4.8$ & $26.7 \pm 4.2$ \\
\hline Waist circumference $(\mathrm{cm})$ & $97.3 \pm 10.8$ & $88.5 \pm 11.5$ \\
\hline Triglycerides (mg/dL) & $233.8 \pm 220.7$ & $129.0 \pm 7.3$ \\
\hline HDL-C (mg/dL) & $36.02 \pm 9.0$ & $48.0 \pm 13.7$ \\
\hline Total cholesterol (mg/dL) & $211.8 \pm 61.5$ & $205.8 \pm 42.4$ \\
\hline $\mathrm{FPG}(\mathrm{mg} / \mathrm{dL})$ & $158.3 \pm 48.1$ & $94.8 \pm 16.9$ \\
\hline Fibrinogen (mg/dL) & $377.0 \pm 89.2$ & $369.1 \pm 71.5$ \\
\hline Uric Acid (mg/dL) & $5.4 \pm 2.8$ & $3.9 \pm 1.3$ \\
\hline hs-CRP (mg/dL) & $1.02 \pm 0.5$ & $0.78 \pm 0.22$ \\
\hline HbAlc (\%) & $5.0 \pm 2.6$ & $4.3 \pm 2.1$ \\
\hline Currents smoking $n(\%)$ & $136(22.4)$ & $45(18.2)$ \\
\hline \multicolumn{3}{|c|}{ Blood pressure $\geq 130 / \geq 85 \mathrm{mmHg}$ or previous diagnosis of hypertension } \\
\hline$n(\%)$ & $301(49.58)$ & \\
\hline Previously diagnosed hypertension $n=(\%)$ & $282(46.45)$ & $23(30.2)$ \\
\hline New cases of hypertension $n=(\%)$ & $19(3.13)$ & \\
\hline \multicolumn{3}{|c|}{ Elevated fasting glucose $\geq 100 \mathrm{mg} / \mathrm{dL}$ or previous diagnosis of T2DM } \\
\hline$n(\%)$ & $398(65.56)$ & \\
\hline Previously T2DM $n=(\%)$ & $165(27.18)$ & $33(30.2)$ \\
\hline New cases of T2DM $n=(\%)$ & $26(4.28)$ & \\
\hline \multicolumn{3}{|c|}{ No T2MD patients with FPG $\geq 100 \mathrm{mg} / \mathrm{dL}-125 \mathrm{mg} / \mathrm{dL} n=(\%) 209$ (34.43) } \\
\hline FH of AT $n(\%)$ & $112(18.45)$ & $30(14.5)$ \\
\hline
\end{tabular}

men $(90.0 \%)$. The prevalence of elevated triglycerides was similar in both groups. There was a similar percent of individuals with elevated fasting glucose $\geq 100 \mathrm{mg} / \mathrm{dL}$ or previous diagnosis of T2DM women $(64.8 \%)$ versus men $(67.3 \%)$. In the group of women $(64.8 \%)$ with the criteria before mentioned, $35.8 \%$ had glucose level between $\geq 100 \mathrm{mg} / \mathrm{dL}$ and $<126 / \mathrm{mg} / \mathrm{dL}$, and $29.0 \%$ had been already diagnosed with T2DM whereas, in the group of men, $33.1 \%$ had $\geq 100 \mathrm{mg} / \mathrm{dL}$ 
TABLe 3: Prevalence (\%) of MS and its components to IDF definition, by gender.

\begin{tabular}{|c|c|c|}
\hline \multirow{3}{*}{ Measure (any 3 of 5 constitute diagnosis of MS) } & Men & Women \\
\hline & \multicolumn{2}{|c|}{ Total $=587$} \\
\hline & $n=190(32.3 \%)$ & $n=397(67.7 \%)$ \\
\hline Age (years) & $53.1 \pm$ & $53.7 \pm$ \\
\hline Waist circumference $n(\%)$ & $190(100 \%)$ & $397(100 \%)$ \\
\hline \multicolumn{3}{|l|}{ Men $\geq 90 \mathrm{~cm}$} \\
\hline \multicolumn{3}{|l|}{ Women $\geq 80 \mathrm{~cm}$} \\
\hline Reduced HDL-C $n(\%)$ & $171(90.0 \%)$ & $370(93.2 \%)$ \\
\hline \multicolumn{3}{|l|}{ Men $<40 \mathrm{mg} / \mathrm{dL}$} \\
\hline \multicolumn{3}{|l|}{ Women $<50 \mathrm{mg} / \mathrm{dL}$} \\
\hline Triglycerides $\geq 150 \mathrm{mg} / \mathrm{dL}$ or medical treatment of elevated TG $n(\%)$ & $142(74.7 \%)$ & $293(73.8 \%)$ \\
\hline Elevated fasting glucose $\geq 100 \mathrm{mg} / \mathrm{dL}$ or previous diagnosis of T2DM & $128(67.3 \%)$ & $257(64.8 \%)$ \\
\hline Blood pressure $\geq 130 / \geq 85 \mathrm{mmHg}$ or previous diagnosis of hypertension $n(\%)$ & $104(54.7 \%)$ & $183(46.1 \%)$ \\
\hline
\end{tabular}

TABLE 4: Prevalence (\%) of MS and its components to AHA/NHLBI definition, by gender.

\begin{tabular}{|c|c|c|}
\hline \multirow{3}{*}{ Measure (any 3 of 5 constitute diagnosis of MS) } & Men & Women \\
\hline & \multicolumn{2}{|c|}{ Total $=510$} \\
\hline & $n=155(30.4)$ & $n=355(69.6 \%)$ \\
\hline Age (years) & $53.6 \pm$ & $53.9 \pm$ \\
\hline Reduced HDL-C $n(\%)$ & $148(95.5 \%)$ & $332(93.5 \%)$ \\
\hline \multicolumn{3}{|l|}{ Men $<40 \mathrm{mg} / \mathrm{dL}$} \\
\hline \multicolumn{3}{|l|}{ Women $<50 \mathrm{mg} / \mathrm{dL}$} \\
\hline Triglycerides $\geq 150 \mathrm{mg} / \mathrm{dL}$ or medical treatment of elevated TG $n(\%)$ & $124(80.0 \%)$ & $270(76.0 \%)$ \\
\hline Elevated fasting glucose $\geq 100 \mathrm{mg} / \mathrm{dL}$ or previous diagnosis of T2DM & $114(73.5 \%)$ & $250(70.4 \%)$ \\
\hline Blood pressure $\geq 130 / \geq 85 \mathrm{mmHg}$ or previous diagnosis of hypertension $n(\%)$ & $101(65.2 \%)$ & $178(50.2 \%)$ \\
\hline Waist circumference $n(\%)$ & $73(47.0 \%)$ & $295(83.0 \%)$ \\
\hline \multicolumn{3}{|l|}{ Men $\geq 102 \mathrm{~cm}$} \\
\hline Women $\geq 88 \mathrm{~cm}$ & & \\
\hline
\end{tabular}

and $<126 / \mathrm{mg} / \mathrm{dL}$, and $34.2 \%$ had been diagnosed with the disease. Hypertension was more common in men $(54.7 \%)$ than in woman $(46.1 \%)$.

Table 4 shows the MS diagnosed based on AHA/NHLBI criterions, and low HDL cholesterol was the most common with a similar frequency in both sexes (men 95.5\%) versus (women 93.5\%), followed by increased triglyceride levels with higher percentage in men $(80.0 \%)$ and women $(76.0 \%)$. There was a slightly high percent of individuals with elevated fasting glucose $\geq 100 \mathrm{mg} / \mathrm{dL}$ or previous diagnosis of T2DM in the group of men (73.5\%) versus women (70.4\%). Hypertension was the least frequent component with $65.2 \%$ in the group of man versus $50.2 \%$ in woman. There was a very significant difference in waist circumference between both groups: men $(47.0 \%)$ versus woman $(83 \%)$.

Table 5 shows the MS diagnosed based on IDF definition and stratified by age ( $\leq \mathrm{y}>45$ years old). There was a higher percent of men in the group of younger individuals, whereas the women were the predominant gender in the older group. Followed by the waist circumference, the reduced HDL$\mathrm{C}$ was the second most frequent criteria with $94.4 \%$ in individuals $\leq 45$ years old versus $>45$ years $(91.5 \%)$. We found a significant difference in elevated triglycerides levels between both groups of age, with higher levels in the young group $(83.3 \%)$ versus the oldest one $(71.6 \%)$. In terms of individuals with previous diagnosis of T2DM or elevated fasting glucose $\geq 100 \mathrm{mg} / \mathrm{dL}$, there was a higher percent in the group of older individuals $(68.3 \%)$ compared to the youngest one $(55.6 \%)$. The percent of elevated blood pressure was higher in the old group against the youngest one $(54.9 \%$ versus $27.0 \%$ ).

Table 6 shows the results of the analysis of individuals with MS diagnosed based on the AHA/NHLBI stratified by age. The female group was predominant in both groups of age in the group of younger women $(61.9 \%)$ and $(69.4 \%)$ in the oldest one. The most common criterion was reduced HDL-C with $97.0 \%$ in the youngest group versus $93.4 \%$ in the old one. In contrast, as we expected we found elevated triglycerides levels in both groups, with higher percent in the group $\leq 45$ years of age $(86.1 \%)$ compared with the oldest group $(75.0 \%)$. There was a slight difference in the percent of waist circumference between the groups ( $\leq 45$ years, $74.3 \%$ versus $>45$ years, 71.6). Increased fasting glucose $\geq 100 \mathrm{mg} / \mathrm{dL}$ or previous diagnosis of T2DM was found in $67.3 \%$ of young individuals versus $72.4 \%<45$ years of age. As it was expected, there was a higher percent of individuals with 
TABle 5: Prevalence (\%) of MS and its components to IDF definition, by age.

\begin{tabular}{|c|c|c|}
\hline \multirow{3}{*}{ Age (years) } & $\leq 45$ & $>45$ \\
\hline & \multicolumn{2}{|c|}{ Total $=587$} \\
\hline & $n=126$ & $n=461$ \\
\hline \multicolumn{3}{|l|}{ Sex $(\%)$} \\
\hline Men & 38.1 & 30.6 \\
\hline Women & 61.9 & 69.4 \\
\hline Waist circumference $n(\%)$ & $126(100)$ & $461(100)$ \\
\hline \multicolumn{3}{|l|}{ Men $\geq 90 \mathrm{~cm}$, women $\geq 80 \mathrm{~cm}$} \\
\hline Reduced HDL-C $n(\%)$ & $119(94.4)$ & $422(91.5)$ \\
\hline \multicolumn{3}{|l|}{ Men $<40 \mathrm{mg} / \mathrm{dL}$} \\
\hline \multicolumn{3}{|l|}{ Women $<50 \mathrm{mg} / \mathrm{dL}$} \\
\hline Triglycerides $\geq 150 \mathrm{mg} / \mathrm{dL}$ or medical treatment of elevated TG $n(\%)$ & $105(83.3)$ & $330(71.6)$ \\
\hline Elevated fasting glucose $\geq 100 \mathrm{mg} / \mathrm{dL}$ or previous diagnosis of T2DM & $70(55.6)$ & $315(68.3)$ \\
\hline Blood pressure $\geq 130 / \geq 85 \mathrm{mmHg}$ or previous diagnosis of hypertension $n(\%)$ & $34(27.0)$ & $253(54.9)$ \\
\hline
\end{tabular}

TABLE 6: Prevalence (\%) of MS and its components to AHA/NHLBI definition, by age.

\begin{tabular}{|c|c|c|}
\hline \multirow{3}{*}{ Age (years) } & $\leq 45$ & $>45$ \\
\hline & \multicolumn{2}{|c|}{ Total $=510$} \\
\hline & $n=101$ & $n=409$ \\
\hline Sex & $53.1 \pm$ & $53.7 \pm$ \\
\hline Men & 38.1 & 30.6 \\
\hline Women & 61.9 & 69.4 \\
\hline Waist circumference $n(\%)$ & $75(74.3)$ & $293(71.6)$ \\
\hline \multicolumn{3}{|l|}{ Men $\geq 102 \mathrm{~cm}$, women $\geq 88 \mathrm{~cm}$} \\
\hline Reduced HDL-C $n(\%)$ & $98(97.0)$ & $382(93.4)$ \\
\hline \multicolumn{3}{|l|}{ Men $<40 \mathrm{mg} / \mathrm{dL}$} \\
\hline \multicolumn{3}{|l|}{ Women $<50 \mathrm{mg} / \mathrm{dL}$} \\
\hline Triglycerides $\geq 150 \mathrm{mg} / \mathrm{dL}$ or medical treatment of elevated TG $n(\%)$ & $87(86.1)$ & $307(75.0)$ \\
\hline Blood pressure $\geq 130 / \geq 85 \mathrm{mmHg}$ or previous diagnosis of hypertension $n(\%)$ & $29(28.7)$ & $250(61.1)$ \\
\hline Elevated fasting glucose $\geq 100 \mathrm{mg} / \mathrm{dL}$ or previous diagnosis of T2DM & $68(67.3)$ & $296(72.4)$ \\
\hline
\end{tabular}

high blood pressure or previous diagnosis of hypertension in the group of $>45$ years of age $(61.1 \%)$ versus $(28.7 \%)$ in the youngest group.

We want to point out that we identified an increased level of fasting overnight glucose $\geq 100 \mathrm{mg} / \mathrm{dL}$ and $<126 \mathrm{mg} / \mathrm{dL}$ in the group of individuals $\leq 45$ years of age when MS was diagnosed by IDF criterions (38.9\%), versus $>45$ years of age $(33.8 \%)$, and when diagnosed by AHA/NHLBI $\leq 45$ years ( $46.5 \%)$ versus $>45$ years old $(35.5 \%)$ (data not shown).

\section{Discussion}

Patients with MS die from complication of T2DM and atherothrombotic disease such as acute myocardial infarction and stroke. In previous studies, a high frequency of metabolic syndrome (MS) has been identified in our population. Therefore, the aim of this study was to identify phenotypic, specific and genotypic profile that may help to improve the prevention of T2DM, dyslipidemia, and atherothrombotic complication such as AMI and Stroke. Although the final results with respect to this principal aim are still awaited, the study clearly confirms that an early screening should be performed in individuals anticipated to be at risk of T2DM, dyslipidemia, and obesity by their primary care physician and should be treated in metabolic syndrome clinic.

The MS was present in $68.7 \%$ of the total sample, according to IDF definitions versus $59.7 \%$, compared with AHA/NHLBI. In $57.2 \%$ of the individuals the MS was diagnosed base by either one definition IDF or AHA/NHLBI. We identify more individuals with MS by IDF classification compared to AHA/NHLBI. This result is probable due to the waist circumference lower cutoff applied by the IDF. In contrast, by AHA/NHLBI, we found an increased percentage of individuals with hypertension, dyslipidemia, and high levels of glucose, compare to IDF classification, because the waist circumference is not an absolute required criterion. This combination of criterions might represent a different severity of the MS between patients classified by one or another.

Those results are in agreement with those previously reported by Rojas et al. [26], who identified a less frequency of the syndrome by AHA/NHLBI compared with IDF in our population, but are in disagreement with those obtained by other investigators in American population $>20$ years [4]. 
Another relevant issue found in this study is the high prevalence of the numbers of criterions in each subject from this sample stratified by groups of age and gender by both classifications IDF and AHA/NHLBI. In the present study, we found a high percent of individuals who fulfilled four or more criterions. However, for the IDF classification, the waist circumference was the most frequent criterion, followed by lowered HDL-C and increased level of triglycerides, whereas for the AHA/NHLBI, the more frequent component was HDL-C, triglycerides, and waist circumference. The most important is that all three criterions are associated with an increased risk for cardiovascular disease, and they are frequently present in the same individual.

In approximately $42.2 \%$ of the individuals $\leq 45$ years of age, who were diagnosed with MS by either classification, IDF, or AHA/NHLBI, registered glucose levels were between $\geq 100 \mathrm{mg} / \mathrm{dL}$ and $125 \mathrm{mg} / \mathrm{dL}$. The most important thing is that they were not under lowering glucose therapy, because they did not have a recent blood glucose test.

On the other hand, as we expect there was a higher percent of individuals with T2DM $>45$ years old $(35.7 \%)$ compared with the subjects $\leq 45$ years old $(18.7 \%)$ in both groups of patients diagnosed with either definition IDF or AHA/NHLBI. Those results corroborated that insulin resistance (IR) is more frequent in young individuals, whereas T2DM is predominant in older individuals. Therefore, an early detection and lifestyle changes have to be implemented in young individuals to avoid the development of chronic disease such as T2DM and atherothrombotic disease complications such acute myocardial infarction and stroke.

Also, similar results were obtained when we analyzed the triglycerides levels by age.

In $73.97 \%$ of individuals with MS diagnosed by either definitions, IDF or AHA/NHLBI were found to have an increased triglycerides levels ( $\geq 150 \mathrm{mg} / \mathrm{dL}$ ), and HDL-C below normal ranges was diagnosed. Most of them had history of dyslipidemia, but only $19.6 \%$ were under lowering lipid therapy. In this particular case is necessary a rigorous and constant monitoring in patients with previous history of dyslipidemia.

Several new features have been added to the syndrome over time. These include elevated plasminogen activator inhibitor-1 (PAI-1) and C-reactive protein (CRP) concentrations. These features were added on the basis that they were frequently found in association with the metabolic syndrome. These features are probably related to both insulin resistance and obesity [27]. In the present study, we failed to identify, an association between high levels of hs-CRP and MS, and those results are in agreement with those previously published by Han et al. [28].

In contrast, we have previously reported that higher levels of plasma PAI-1 represent a risk factor for development of ST elevation acute myocardial infarction (STEAMI) [29].

Therefore, the following step will be determinate PAI-1 levels in the same group of patients with MS. Those results probabley allow us to include a new atherothrombotic marker in this type of patients in our population.

A previous study by Madrid-Miller [30] explores the clinical impact of MS in patients with acute coronary syndrome
(ACS). The MS was more frequent in older patients with ACS and was associated with poorer in-hospital outcomes.

Since most patients with T2DM die from complications of atherosclerosis, they should receive intense preventive interventions proven to reduce their cardiovascular risk.

Using the AHA/NHLBI definitions, MS is present in 82.3 of self-reported coronary heart diseases (CHD), $87.5 \%$ of type 2 diabetes cases, $43.1 \%$ self-reported with high triglycerides, $47.6 \%$ of subjects with low HDL-cholesterol levels, and $70.5 \%$ of adults with hypertension [26].

That percentage provides a gross estimate of the contribution of MS to the outcomes mentioned above and justifies the screening of MS components in persons with those conditions. These results will be useful for updating local guidelines for the prevention and treatment of specific chronic disorders, which requires a multidisciplinary team approach that implements lifestyle changes and a combination of drugs (when appropriate). The primary goal of clinical management in individuals with MS is to reduce the risk of clinical atherosclerosis disease.

Therefore, our data describes the significant challenges that MS represents to our health system. The Mexican health system should develop specific management programs for all identified cases; failure to identify or treat cases of MS will result in a considerable increase in new forms of T2DM and/or CHD.

\section{Conclusions}

Our results identify that more than $40 \%$ of individuals with MS has four or more criterions, which represent the severity of the syndrome among urban Mexican sample. Therefore, strong strategies had to be developed for early detection of MS and its components in order to prevent DMT2 and atherothrombotic complications in these patients with myocardial infarction and stoke.

\section{Conflict of Interests}

The authors declare that there is no conflict of interests.

\section{Acknowledgments}

This research was supported by El Fondo de Investigación en Salud IMSS Grant (FIS/IMSS/PROT/G09/748) (FIS/IMSS/ PROT/541) by CONACyT (Consolidación de Grupos de Investigación modalidad repatriación no. 050232), and by Apoyo Complementario para Investigadores Nivel 1 no. 118254 (to Dr. I. Isordia-Salas) (FIS/IMSS/PROT/541). The authors want to thank the clinical laboratory staff at the Hospital "Dr. Carlos Mac Gregor Sánchez Navarro" for the invaluable contribution to this study.

\section{References}

[1] G. M. Reaven, "Role of insulin resistance in human disease," Diabetes, vol. 37, no. 12, pp. 1595-1607, 1988.

[2] K. G. M. M. Alberti and P. Z. Zimmet, "Definition, diagnosis and classification of diabetes mellitus and its complications. 
Part 1: diagnosis and classification of diabetes mellitus. Provisional report of a WHO consultation," Diabetic Medicine, vol. 15, no. 7, pp. 539-553, 1998.

[3] J. I. Cleeman, "Executive summary of the third report of the national cholesterol education Program (NCEP) expert panel on detection, evaluation, and treatment of high blood cholesterol in adults (adult treatment panel III)," Journal of the American Medical Association, vol. 285, no. 19, pp. 2486-2497, 2001.

[4] K. G. M. M. Alberti, P. Zimmet, and J. Shaw, "Metabolic syndrome-A new world-wide definition. A consensus statement from the international diabetes federation," Diabetic Medicine, vol. 23 , no. 5, pp. 469-480, 2006.

[5] E. S. Ford, "Risks for all-cause mortality, cardiovascular disease, and diabetes associated with the metabolic syndrome: a summary of the evidence," Diabetes Care, vol. 28, no. 7, pp. 1769-1778, 2005.

[6] P. Bustos, K. Saez, A. Gleisner, N. Ulloa, C. Calvo, and S. Asenjo, "Metabolic syndrome in obese adolescents," Pediatric Diabetes, vol. 11, no. 1, pp. 55-60, 2010.

[7] R. P. Hoffman, "Metabolic syndrome racial differences in adolescents," Current Diabetes Reviews, vol. 5, no. 4, pp. 259-265, 2009.

[8] B. Balkau, T. Drivsholm, K. Borch-Johnsen et al., "Frequency of the who metabolic syndrome in European cohorts, and an alternative definition of an insulin resistance syndrome," Diabetes and Metabolism, vol. 28, no. 5, pp. 364-376, 2002.

[9] J. Escobedo, H. Schargrodsky, B. Champagne et al., "Prevalence of the metabolic syndrome in Latin America and its association with sub-clinical carotid atherosclerosis: The CARMELA cross sectional study," Cardiovascular Diabetology, vol. 8, article 1475, p. 52, 2009.

[10] F. Márquez-Sandoval, G. Macedo-Ojeda, D. ViramontesHörner, J. Fernández Ballart, J. Salas Salvadó, and B. Vizmanos, "The prevalence of metabolic syndrome in Latin America: a systematic review," Public Health Nutrition, vol. 14, no. 10, pp. 1702-1713, 2011.

[11] F. Abbasi, B. W. Brown, C. Lamendola, T. McLaughlin, and G. M. Reaven, "Relationship between obesity, insulin resistance, and coronary heart disease risk," Journal of the American College of Cardiology, vol. 40, no. 5, pp. 937-943, 2002.

[12] R. C. Bonadonna, D. Cucinotta, D. Fedele, G. Riccardi, and A. Tiengo, "The metabolic syndrome is a risk indicator of microvascular and macrovascular complications in diabetes: results from metascreen, a multicenter diabetes clinic-based survey," Diabetes Care, vol. 29, no. 12, pp. 2701-2707, 2006.

[13] E. Bonora, G. Targher, G. Formentini et al., "The Metabolic Syndrome is an independent predictor of cardiovascular disease in Type 2 diabetic subjects. Prospective data from the Verona Diabetes Complications study," Diabetic Medicine, vol. 21, no. 1, pp. 52-58, 2004.

[14] P. Dandona, A. Aljada, A. Chaudhuri, P. Mohanty, and R. Garg, "Metabolic syndrome: a comprehensive perspective based on interactions between obesity, diabetes, and inflammation," Circulation, vol. 111, no. 11, pp. 1448-1454, 2005.

[15] G. Hu, Q. Qiao, and J. Tuomilehto, "The metabolic syndrome and cardiovascular risk," Current Diabetes Reviews, vol. 1, no. 2, pp. 137-143, 2005.

[16] S. Mottillo, K. B. Filion, J. Genest et al., "The metabolic syndrome and cardiovascular risk: a systematic review and meta-analysis," Journal of the American College of Cardiology, vol. 56, no. 14, pp. 1113-1132, 2010.

[17] E. J. Dunn and P. J. Grant, "Type 2 diabetes: an atherothrombotic syndrome," Current Molecular Medicine, vol. 5, no. 3, pp. 323-332, 2005.
[18] E. S. Ford, "Risks for all-cause mortality, cardiovascular disease, and diabetes associated with the metabolic syndrome: a summary of the evidence," Diabetes Care, vol. 28, no. 7, pp. 1769-1778, 2005.

[19] J. A. Beckman, M. A. Creager, and P. Libby, "Diabetes and atherosclerosis epidemiology, pathophysiology, and management," Journal of the American Medical Association, vol. 287, no. 19, pp. 2570-2581, 2002.

[20] D. M. Lloyd-Jones, Y. Hong, D. Labarthe et al., "Defining and setting national goals for cardiovascular health promotion and disease reduction: the american heart association's strategic impact goal through 2020 and beyond," Circulation, vol. 121, no. 4, pp. 586-613, 2010.

[21] Instituto Nacional de Estadística, "Geografía e informática. Censo vacional de población y vivienda," México, 2007, http://www.inegi.org.mx/.

[22] I. Isordia-Salas, A. Leaños-Miranda, and G. Borrayo-Sánchez, "The Glu298ASP polymorphism of the endothelial nitric oxide synthase gene is associated with premature ST elevation myocardial infarction in Mexican population," Clinica Chimica Acta, vol. 411, no. 7-8, pp. 553-557, 2010.

[23] I. Isordia-Salas, F. Barinagarrementería-Aldatz, A. LeañosMiranda et al., "The C677T polymorphism of the methylenetetrahydrofolate reductase gene is associated with idiopathic ischemic stroke in the young mexican-mestizo population," Cerebrovascular Diseases, vol. 29, no. 5, pp. 454-459, 2010.

[24] W. T. Friedewald, R. I. Levy, and D. S. Fredrickson, "Estimation of the concentration of low-density lipoprotein cholesterol in plasma, without use of the preparative ultracentrifuge," Clinical Chemistry, vol. 18, no. 6, pp. 499-502, 1972.

[25] S. M. Grundy, J. I. Cleeman, S. R. Daniels et al., "Diagnosis and management of the metabolic syndrome: an American heart association/National heart, lung, and blood institute scientific statement," Circulation, vol. 112, no. 17, pp. 2735-2752, 2005.

[26] R. Rojas, C. A. Aguilar-Salinas, A. Jiménez-Corona et al., "Metabolic syndrome in Mexican adults: results from the national health and nutrition survey 2006," Salud pública de México, vol. 52, pp. S11-18, 2010.

[27] P. Dandona, A. Aljada, A. Chaudhuri, P. Mohanty, and R. Garg, "Metabolic syndrome: a comprehensive perspective based on interactions between obesity, diabetes, and inflammation," Circulation, vol. 111, no. 11, pp. 1448-1454, 2005.

[28] T. S. Han, N. Sattar, K. Williams, C. Gonzalez-Villalpando, M. E. J. Lean, and S. M. Haffner, "Prospective study of Creactive protein in relation to the development of diabetes and metabolic syndrome in the Mexico City diabetes study," Diabetes Care, vol. 25, no. 11, pp. 2016-2021, 2002.

[29] I. Isordia-Salas, A. Leaños-Miranda, I. M. Sainz, E. ReyesMaldonado, and G. Borrayo-Sánchez, "Association of the plasminogen activator inhibitor-1 gene 4G/5G polymorphism with ST elevation acute myocardial infarction in young patients," Revista Espanola de Cardiologia, vol. 62, no. 4, pp. 365372, 2009.

[30] A. Madrid-Miller, A. Alcaraz Ruiz, G. Borrayo Sánchez, E. Almeida Gutiérrez, R. M. Vargas Guzmán, and R. Jáuregui Aguilar, "Metabolic syndrome: clinical and angiographic impact on patients with acute coronary syndrome," Cirugia y Cirujanos, vol. 78, no. 2, pp. 113-120, 2010. 


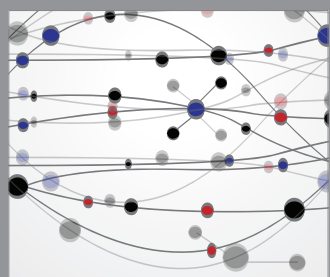

The Scientific World Journal
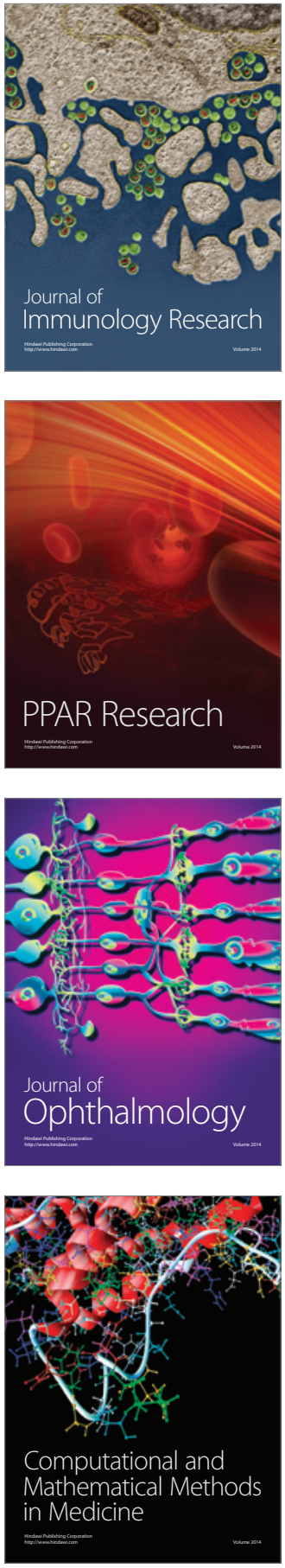

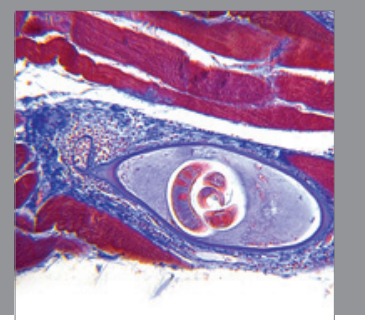

Gastroenterology

Research and Practice
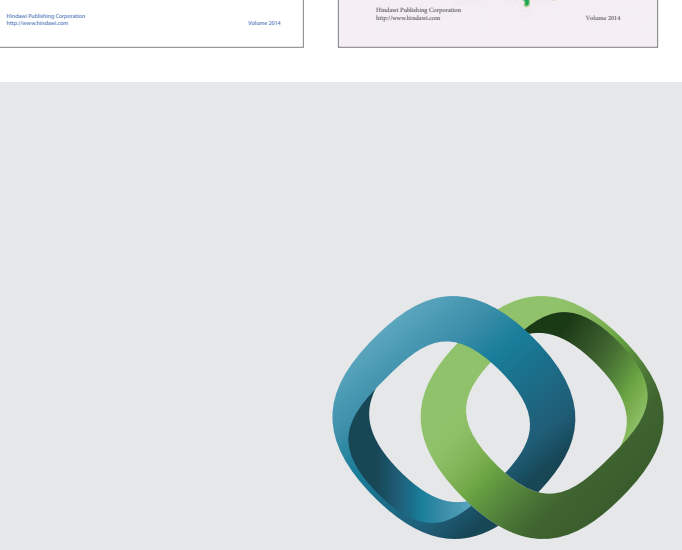

\section{Hindawi}

Submit your manuscripts at

http://www.hindawi.com
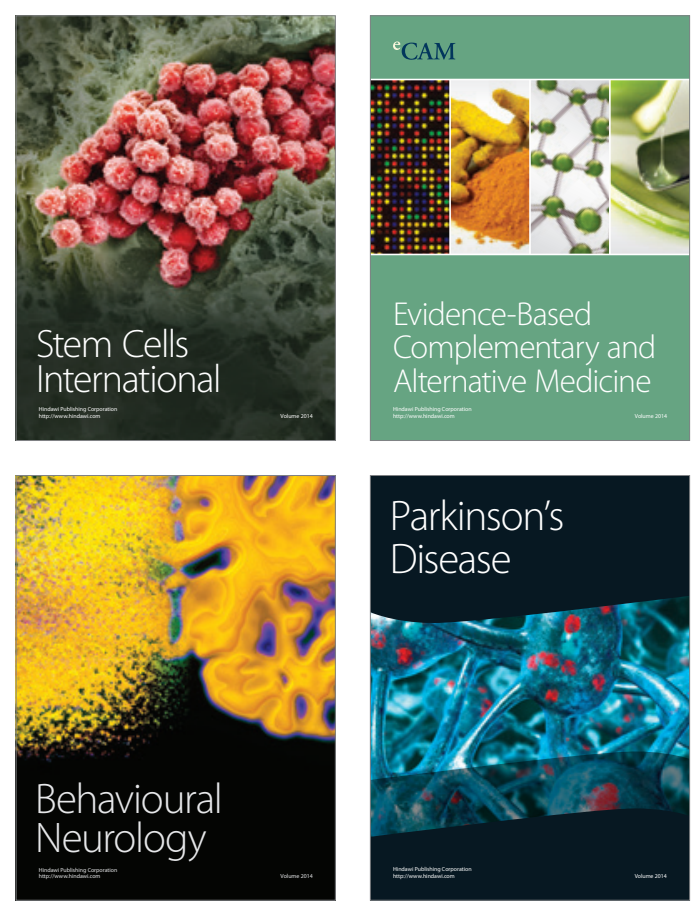

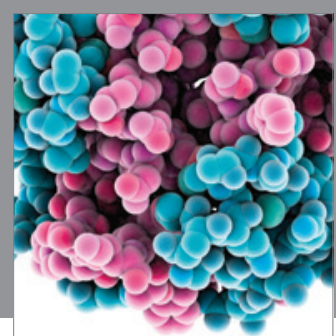

Journal of
Diabetes Research

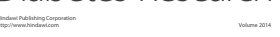

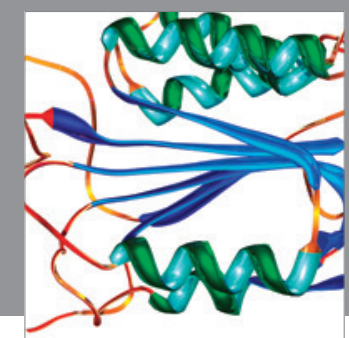

Disease Markers
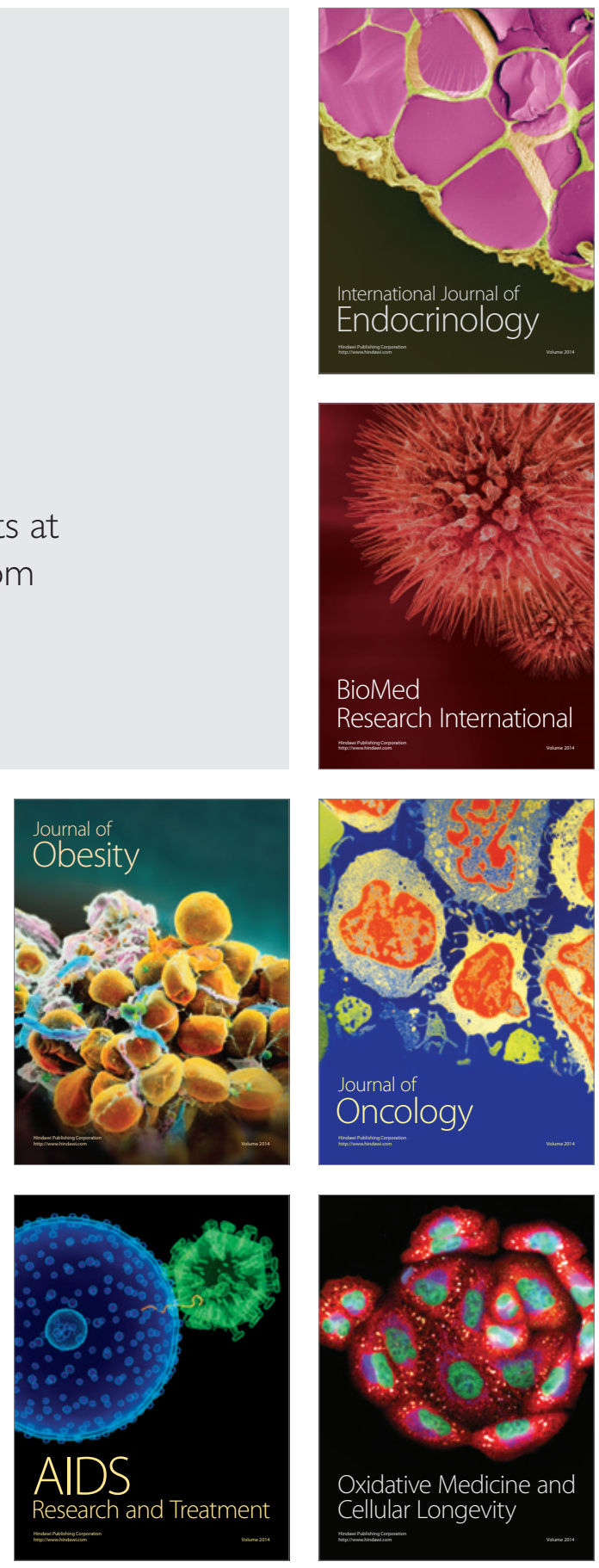